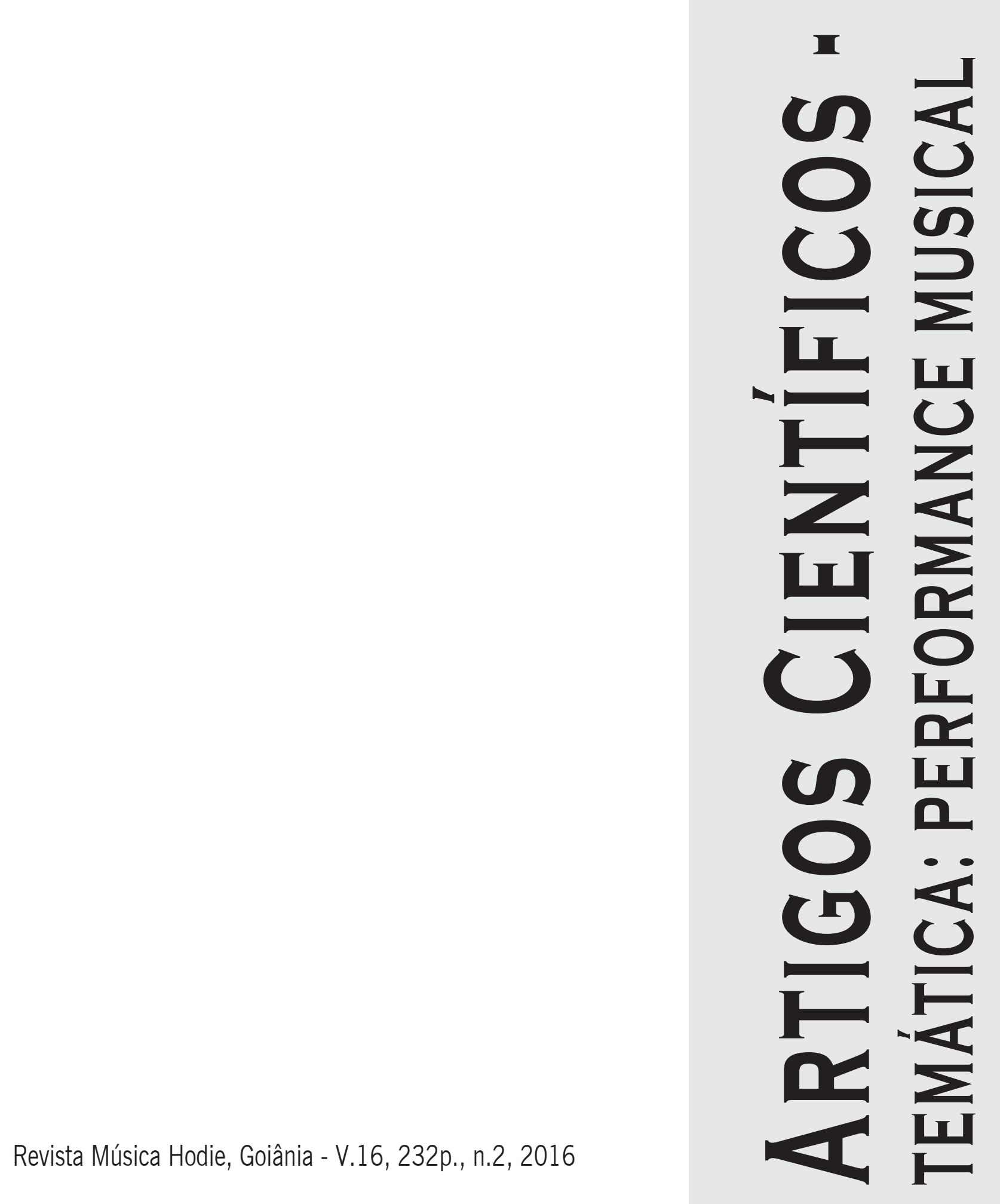




\title{
Prelúdios ou estudos: dualidade nos prelúdios para violino solo de Flausino Vale
}

\author{
Hermes Cuzzuol Alvarenga (Universidade Federal da Paraíba, João Pessoa, PB, Brasil) \\ hcalvarenga@hotmail.com \\ Paulo Leniuson Ribeiro (Faculdade Darcy Ribeiro, Fortaleza, CE, Brasil) \\ pauloleniuson@hotmail.com
}

\begin{abstract}
Resumo: Este artigo busca qualificar o uso dos 26 Prelúdios Característicos e Concertantes para Violino Só, de Flausino Vale, como estudo técnico violinístico. Esta análise foi baseada em metodologia fundamentada primariamente na recorrência e na homogeneidade da apresentação dos fundamentos técnicos em cada prelúdio. Concluiu-se que Vale não concebeu os prelúdios com objetivo didático que posteriormente e, em parte, foi ensejado pelo alcance público desta obra durante sua vida. Concluiu-se ainda que os prelúdios selecionados são importantes como material didático não só pelo que representam sob o ponto de vista violinístico, mas também por sua associação com a linguagem musical brasileira.
\end{abstract}

Palavras-chave: Flausino Vale; Prelúdios para violino solo; Música brasileira para violino.

Preludes or studies: dualism in the preludes for violin solo of Flausino Vale

Abstract: This article seeks to identify the potential use of Flausino Vale's 26 Prelúdios Característicos e Concertantes para Violino Só as violin studies. The applied methodology has focused primarily on the recurrence and reiteration of fundamental aspects in each one of the preludes. To conclude we demonstrate that Vale had not originally conceived the preludes for instructional purposes. However due to the level of success the works gained from public exposition during his lifetime, we consider the selected preludes as being important for teaching the violin not only because what they represent in instrumental terms, but also because the traditional technical foundations in which they are based well represent Brazilian musical culture.

Keywords: Flausino Vale; Preludes for violin solo; Brazilian music for the violin.

Preludios o estudios: dualidad en los preludios para violino solo de Flausino Vale

Resumen: Este artículo procura identificar el potencial uso de los 26 Preludios Característicos e Concertantes para Violino Só de Flausino Vale, como estúdio para el violín. Este análisis se basa em una metodología, sustentada en la recurrencia y forma homogénea de la presentación de los fundamentos técnicos. Concluimos, pues, ser plausible considerar que Vale no concibió los preludios con fines didácticos y que su deseo en esta dirección fue posterior. Los preludios seleccionados, no son importantes solamente como material didáctico por lo que representan sobre el punto de vista estrictamente violinistico, sino también, por el hecho de que esos fundamentos técnicos tradicionales encontrados están asociados al lenguaje musical brasileño.

Palabras clave: Flausino Vale; Preludios para violín solo; La música brasileña para violín solo.

\section{Introdução}

O repertório brasileiro para violino ainda é reduzido quando se busca por literatura brasileira dirigida para a formação técnica do violinista. Estudos técnicos para o violino por compositores brasileiros são praticamente inexistentes na literatura nacional. A tradição europeia de compositores/violinistas que escreviam estudos e caprichos de orientação didática, além de obras concertantes, é inexistente no Brasil. Acreditamos, porém, ser correto afirmarmos que há na literatura musical brasileira um compositor que nos remete ao conhecido modelo europeu do violinista que escrevia e executava suas próprias obras para o violino. Flausino Rodrigues Vale (1894-1954) foi por décadas celebrado em Belo Horizonte por seus dotes artísticos como violinista e compositor, mas era pouco conhecido além desta fronteira. Seu nome passou a ter maior destaque entre os violinistas em geral quando uma de suas obras, o Prelúdio XV, intitulado Ao Pé da Fogueira foi gravado pelo celebrado violinista Jascha Heifetz (1901-1987). Este prelúdio, originalmente escrito para violino solo, foi arranjado, editado e gravado por Heifetz na versão para violino e piano, sendo esta a forma 
que ficou amplamente conhecida. Posteriormente à sua publicação o prelúdio no arranjo para violino e piano foi gravado por alguns dos mais importantes violinistas ativos no cenário internacional do Sec. XX. Embora Vale tenha repercutido positivamente à exposição e divulgação internacional de uma de suas obras, sentia-se frustrado por não ter o mesmo reconhecimento entre os violinistas brasileiros.

Vale compôs vinte e seis prelúdios para violino solo, além de outras obras e arranjos para o instrumento. O conjunto de prelúdios é a sua principal obra e tem o título original de: 26 Prelúdios Característicos e Concertantes para Violino Só. Vale nunca explicou claramente como Heifetz descobriu Ao Pé da Fogueira e é possível que tanto o arranjo quanto a gravação tenham sido feitos à revelia do conhecimento e autorização do compositor. A ideia inicial dos prelúdios surgiu com a composição da Suíte Mineira. Vale denominou esta suíte a partir de uma coletânea com as nove primeiras peças que escreveu para violino solo ainda sem a indicação de prelúdios. Só a partir de 1930 Vale partiu para a idealização dos prelúdios como hoje conhecemos. A partir de então as peças da suíte passaram a integrar o conjunto de prelúdios.

Frésca cita uma carta de Vale para Curt Lange, escrita em 1953, onde o compositor expressa claramente seu desejo de ver seus prelúdios utilizados também como estudos de aperfeiçoamento técnico (FRÉSCA, 2010, p. 151). Vale acreditava que seus prelúdios poderiam ser utilizados tanto nas salas de concertos, como para fins didáticos na forma de estudos técnicos para o violino. Entretanto, esta afirmação do compositor só aparece tardiamente, no início dos anos 1950, quando Vale já havia concluído todos os seus prelúdios.

Este artigo busca, portanto, clarificar a hipótese de que os prelúdios têm de fato potencial para servir ao objetivo didático desejado pelo compositor. É provável que essa característica não se aplique indistintamente aos prelúdios, já que foram concebidos primariamente como obras concertantes. No decorrer desta análise iremos buscar e identificar elementos que possam conferir a estas peças caráter que lhes permitam proximidade com o gênero estudo como o conhecemos. Acredita-se que estas características, quando identificadas, colocarão a linguagem violinística destes prelúdios próxima àquela que encontramos regularmente nos estudos e obras de compositores violinistas europeus do Sec. XIX. Em decorrência do escopo reduzido deste artigo, procuraremos fazer uma amostragem seletiva daqueles prelúdios que de forma objetiva possam ser definidos também como estudos. Embora não de forma restrita, a abordagem desta análise irá focar sua maior atenção aos elementos de fundamentação técnica da mão esquerda. Entende-se, portanto, que ao se identificar melhor esta dualidade dos prelúdios entre peça concertante e didática estaremos contribuindo de forma positiva para uma compreensão ainda melhor desta obra ímpar no repertório violínistico brasileiro.

\section{Flausino Vale}

No início dos anos de 1980 Vale ainda era essencialmente conhecido por seu Prelúdio XV e pouco se sabia sobre sua produção composicional. Em 1985 o violinista polonês, radicado no Brasil, Jerzy Milewski gravou uma coletânea com vinte e um prelúdios (MILEWSKI, 1984). Esta foi certamente a maior visibilidade que a obra de Vale havia recebido até então, excetuando-se a exposição prévia do Prelúdio XV, Ao Pé da Fogueira. A partir daquele momento chamou-se a atenção para um compositor que aparentemente se sustentava como autor de uma única obra de destaque. É plausível afirmar que Milewski pode ter desejado gravar a totalidade dos prelúdios, mas naquele momento vários prelúdios encon- 
travam-se perdidos e nem mesmo a família do compositor sabia o destino daquelas partituras. A partir de uma pesquisa sobre Vale e os prelúdios iniciada por Alvarenga em 1990, obteve-se como um dos primeiros resultados a recuperação da integralidade das partituras, recompondo-se assim a totalidade de vinte e seis peças. Em 1993 a pesquisa foi concluída e resultou em uma dissertação de mestrado defendida na Universidade Federal do Rio Grande do Sul (ALVARENGA, 1993). Este trabalho tornou-se referencial e deu origem a novos textos e pesquisas de outros autores que resultaram em artigos, livros, edição das partituras e uma gravação integral dos prelúdios. Vale é hoje um compositor com seu lugar bem definido na música brasileira; e o conjunto dos 26 Prelúdios, considerado sua principal obra, está plenamente acessível.

A produção musical de Vale contempla os mais diversificados formatos que vão desde peças para violino e piano, violino solo, obras para orquestra, além de diversos arranjos. Vale, no entanto, dispensava uma atenção especial às obras para violino sem acompanhamento, ou para 'violino só', como o próprio compositor denominava. Os prelúdios são peças de curta duração e com estrutura musical simples, quase todos monotemáticos e obedecendo a um padrão baseado na repetição de frases e na utilização de variados recursos técnicos violinísticos. As referências temáticas dos prelúdios estão associadas a cultura popular e folclórica, fontes que eram relativamente familiares ao compositor. Embora muitos prelúdios sejam apresentados na forma A-B-A, outros nos remetem a uma forma simplificada de variações sobre um tema. Uma observação mais atenta revela que algumas dessas peças se sustentam mais pelo uso inteligente dos recursos técnicos da linguagem violinística, do que propriamente por seus méritos musicais.

Vale nasceu em Barbacena MG, mas viveu praticamente toda sua vida adulta em Belo Horizonte. Nessa cidade compôs, atuou como violinista, professor de história da música e, paralelamente, exerceu a profissão de advogado. Sua obra de maior destaque é a coleção de vinte e seis prelúdios para violino solo, escrito entre 1922 e a década de 1940. Vale foi ativo também como escritor, deixou artigos para jornais, revistas e um livro de poesias de título Calidoscópio (1923). Posteriormente escreveu Elementos do Folclore Musical Brasileiro (1936) ${ }^{1}$ e Músicos Mineiros (1948). Em seu texto de 1936 Vale pesquisou as raízes da nossa música expressando seu entendimento sobre as influências deixadas pelos índios, negros e pela cultura europeia, concluindo assim com definições dos elementos, que segundo o autor, são característicos da música brasileira.

Sua formação violinística foi de pouco mais de quatro anos de estudo com seu tio materno João Augusto Campos ${ }^{2}$ enquanto vivia em Barbacena. Com a ida de Campos para o Rio de Janeiro, Vale se transferiu para Belo Horizonte em 1912 no intuito de prosseguir nos estudos do violino, fato que na prática não ocorreu. Após sua chegada à capital mineira Vale passou a integrar orquestras de cinemas, complementando ainda sua renda tocando em serviços religiosos e cerimônias. Enquanto conduzia sua vida de violinista e compositor, Vale também cursou a faculdade de Direito formando-se bacharel em 1923.

Em 1927 Vale entrou para o corpo docente do Conservatório Mineiro de Música como professor de História da Música, disciplina que lecionou por toda a sua vida. No início da década de 1930, acumulava os cargos de professor do conservatório, advogado e spalla da Sociedade de Concertos Sinfônicos. Neste mesmo período, teve a sua primeira atuação como solista à frente desta mesma orquestra, executando o Concerto de Mendelssohn em mi menor para violino e orquestra. Seu primeiro recital deu-se em 1935, na cidade mineira de Sete Lagoas. Neste recital Vale incluiu quatro dos seus prelúdios: Batuque, Repente, Rondó Doméstico e Folguedo Campestre. Embora tenha tido um curto período de estudo do instrumento, Vale era considerado pela impressa local e por quem o conhecia como um violinis- 
ta que encantava a todos com sua espontaneidade ao instrumento. Em programa de um dos seus concertos, datado de 26 de junho de 1927, Vale é apresentado como 'sobejamente conhecido da plateia local' e celebrado 'por sua excepcional virtuosidade'.

Naquele tempo, sua fama já havia ultrapassado as fronteiras de Minas Gerais. Muricy relembra em um artigo jornalístico que ao entrar no gabinete de Villa-Lobos, no Conservatório Nacional de Canto Orfeônico no Rio de Janeiro, este apresentou-lhe Flausino Vale e declarou: "É um novo Paganini!" (MURICY, 1948). Anteriormente ao relato de Muricy palavras de admiração dirigidas a Vale já tinham sido ditas por Villa-Lobos em uma palestra no Conservatório Mineiro de Música em Belo Horizonte, conforme relatou o crítico musical Celso Brant em um artigo no jornal Diário da Tarde reportando a fala de Villa-Lobos. De acordo com BRANDT (1947) nesta ocasião Villa-Lobos referiu-se a Vale como sendo uma extraordinária revelação de arte, relatando sua primeira impressão após ouvi-lo pessoalmente em seu apartamento no Rio de Janeiro havia pouco tempo.

\section{Conceitos e critérios de inclusão dos prelúdios}

Não obstante ao desejo do compositor de ver seus prelúdios usados também para fins didáticos, as análises existentes dos prelúdios apresentadas até o momento não se aproximam deste universo. Carecem, portanto, de uma abordagem mais específica no sentido de procurar clarificar a extensão do conteúdo da linguagem violinística nos prelúdios com potencial associado a aplicação pedagógica. É possível notar que Vale reproduz em seus prelúdios características técnicas semelhantes àquelas encontradas em estudos técnicos tradicionais para violino. Embora esta proximidade seja perceptível em alguns prelúdios, há também outros onde existe diluição do foco pela utilização de fundamentos técnicos diversos. Há também que se observar que a presença de elementos conceituais da linguagem violinística própria do compositor em alguns prelúdios enfraquece a tentativa de conferir status de estudo a todos os prelúdios. Isso exposto, defendemos a hipótese de que existem prelúdios mais funcionais do que outros para serem classificados e utilizados como estudos técnicos para o violino.

O formato composicional dos prelúdios, apresenta fraseado musical com estrutura melódica e harmônica simples. Neste contexto, a importância dada ao uso dos recursos técnicos do instrumento é determinante para criar variedade além do universo temático. Embora o uso de recursos técnicos do violino seja notável nestas peças, a ideia sugestiva de descrição e imitação, consequência da associação do domínio de Vale na escrita violinística com sua linguagem musical, dão aos prelúdios o estilo de peça característica como expressado em seu título. Em alguns de seus prelúdios Vale procura reproduzir ideias a partir de percepções sonora utilizando como ferramentas a própria intuição e a experimentação. Vale procura reproduzir no violino sonoridades semelhantes, ou que, dentro das limitações do instrumento faça referência a sons da natureza ou ao estilo de música que sugira o ambiente sonoro que lhe era familiar. Alguns dos títulos dados aos prelúdios são sugestivos no que diz respeito às referências sonoras e às ideias musicais captadas por Vale. Como exemplo podemos citar: Casamento na Roça, A Porteira da Fazenda e Canto da Inhuma. Outros, entretanto, apresentam característica mais concertante, explorando pontualmente os aspectos da técnica instrumental. A abordagem virtuosística no uso dos recursos do violino nos prelúdios é preponderantemente influenciada pelas nuances técnicas encontradas no repertório tradicional do instrumento, especialmente nas obras escritas por compositores violinistas da Europa no século XIX. 


\subsection{Prelúdios em forma de estudos}

Na tabela a seguir estão listados os prelúdios que em nosso entendimento melhor representam o gênero estudo dentre os vinte e seis prelúdios analisados. A escolha não pretende ser definitiva pois seguiu critérios analíticos próprios que podem sofrer variantes de alguns poucos fatores subjetivos de acordo com conceitos individuais de cada pesquisador. Entretanto, esta abordagem visou buscar referências nos mais sólidos elementos possíveis quanto a recorrência de fundamentos que evidencie em cada prelúdio o foco em um determinado interesse técnico.

Tabela 1: Prelúdios que mostram potencial para uso como estudos técnicos.

\begin{tabular}{|l|c|}
\hline \multicolumn{1}{|c|}{ Prelúdios } & Ano de Composição \\
\hline II - Suspiros d'Alma & 1923 \\
\hline III - Devaneio & 1924 \\
\hline V - Tico-tico & 1926 \\
\hline VI - Marcha Fúnebre & 1927 \\
\hline VIII - Repente & 1924 \\
\hline IX - Rondo'Doméstico & 1933 \\
\hline XIII - Asas Inquietas & $193 ?$ \\
\hline XV - Ao Pé da Fronteira & $193 ?$ \\
\hline
\end{tabular}

\begin{tabular}{|l|c|}
\hline \multicolumn{1}{|c|}{ Prelúdios } & Ano de Composição \\
\hline XVI - Requiescat In Pace & $19 ? ?$ \\
\hline XIX - Folguedo Campestre & $19 ? ?$ \\
\hline XXI - Prelúdio da Vitória & $19 ? ?$ \\
\hline XXII - Mocidade Eterna & $194 ?$ \\
\hline XXIV - Viva São João & $194 ?$ \\
\hline XXV - A Mocinha e o papudo & $194 ?$ \\
\hline XXVI - Acalanto & $194 ?$ \\
\hline
\end{tabular}

Onze prelúdios foram excluídos por não apresentarem as características técnicas desejadas para classificá-los como estudo. No Prelúdio VII, Sonhando, por exemplo, encontramos relevante uso de sextas que poderia sugerir sua aplicação como estudo deste fundamento. Entretanto, a maneira de execução em pizzicato com o violino posicionado em uma maneira incomum, a la guitarra, o colocou fora desta lista.

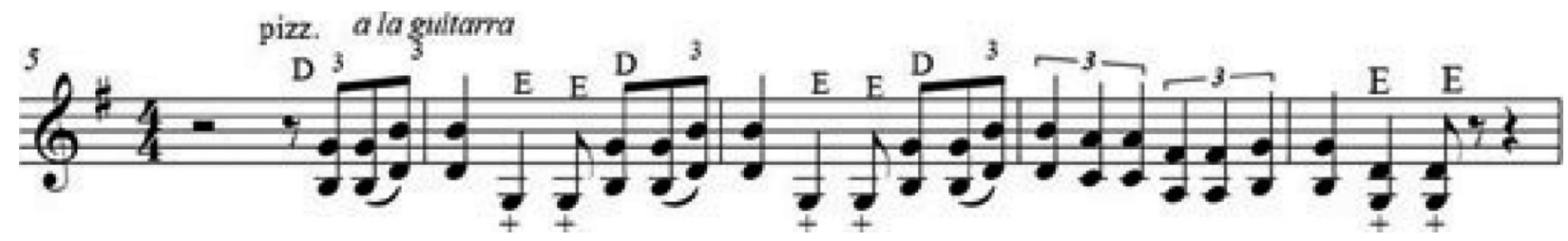

Figura 1: Prelúdio VII "Sonhando". Comp. 5 - 9.

Por diferentes razões são excluídos outros como o Prelúdio IV, Brado Íntimo e Prelúdio $X$, Interrogando o Destino que apresentam distribuição heterogênea de recursos técnicos não se situando, portanto, em um objetivo específico como desejado nesta análise.
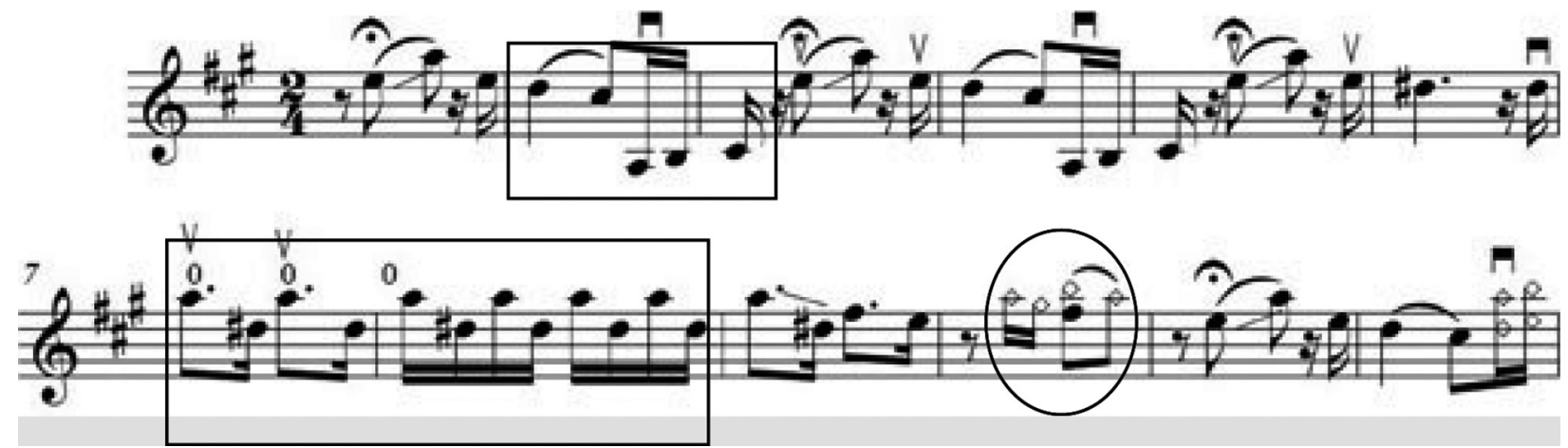

Figura 2: Prelúdio IV - Brado Íntimo. Comp. 1 - 12. 


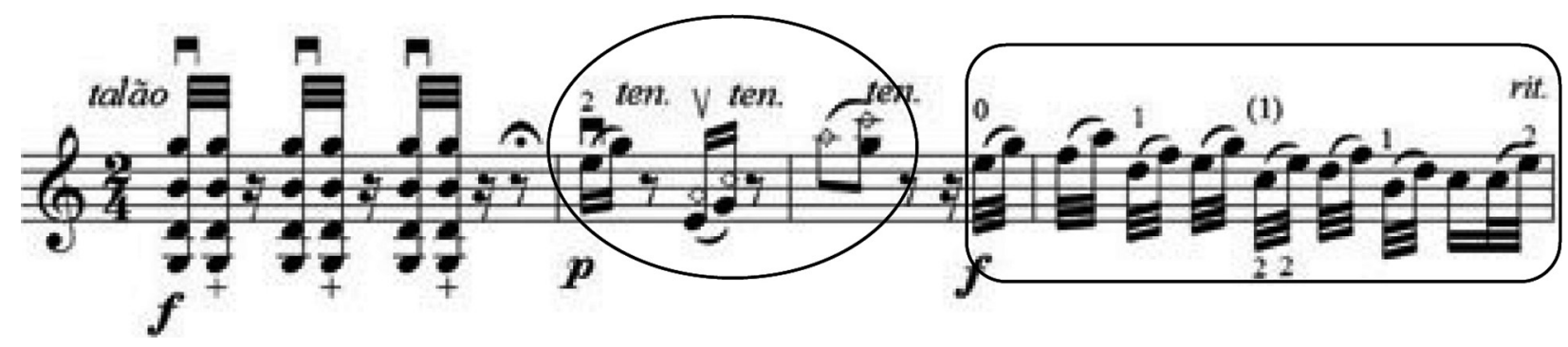

Figura 3: Prelúdio X - Interrogando o Destino. Comp. 1 - 4 .

É importante observarmos a perspectiva em que cada prelúdio se enquadra em relação ao formato analítico usado. O procedimento utilizado para a seleção e exclusão das obras não deve ser encarado como parâmetro de nivelamento no que diz respeito ao nível de técnica composicional, tampouco representa uma visão crítica sobre os procedimentos utilizados pelo compositor na concepção dos prelúdios. Os critérios utilizados nesta análise visam unicamente selecionar aqueles que apresentam em sua estrutura aparato técnico potencialmente viável para a aplicação como estudo técnico para o violino. Nesse sentido, a exclusão de alguns prelúdios neste artigo deve-se apenas ao método utilizado nesta análise, que se baseou no perfil dos procedimentos técnicos comumente encontrados nos métodos tradicionais de violino de compositores como Kreutzer, Rode, Gaviniès e Dont. A seguir iremos demonstrar, em prelúdios selecionados dentre os listados na Tabela 1, algumas características que deram suportes à classificação potencial destes como estudos técnicos para o violino.

Um dos mais emblemáticos de todos os prelúdios de Vale a representar o gênero estudo em sua escrita é o Prelúdio V, Tico-Tico.

Melodia
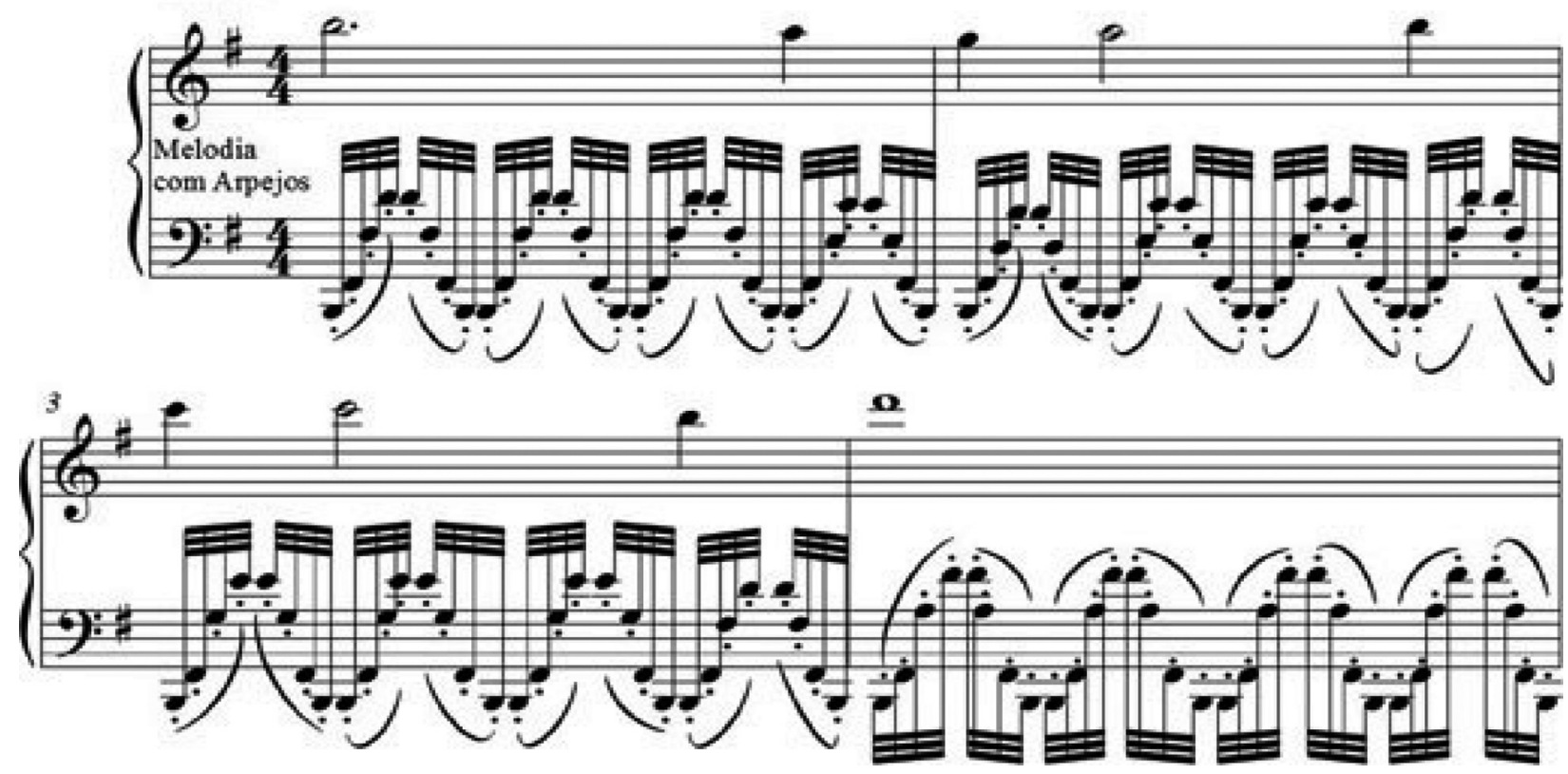

Figura 4: Prelúdio V - Tico-Tico. Comp. 1 - 4.

Observa-se que durante os arpejos, a $4^{\mathrm{a}}$ e $3^{\mathrm{a}}$ cordas permanecem soltas ${ }^{3}$, formando um pedal harmônico de Sol e Ré. Sobre esta base a mão esquerda se encarrega de montar toda a sequência de intervalos, na linha melódica desenvolvida na primeira corda, que está diretamente atrelada a intervalos como os de sextas, sétimas, nonas e décimas, dedilhados na $1^{\mathrm{a}}$ e $2^{\mathrm{a}}$ cordas. 


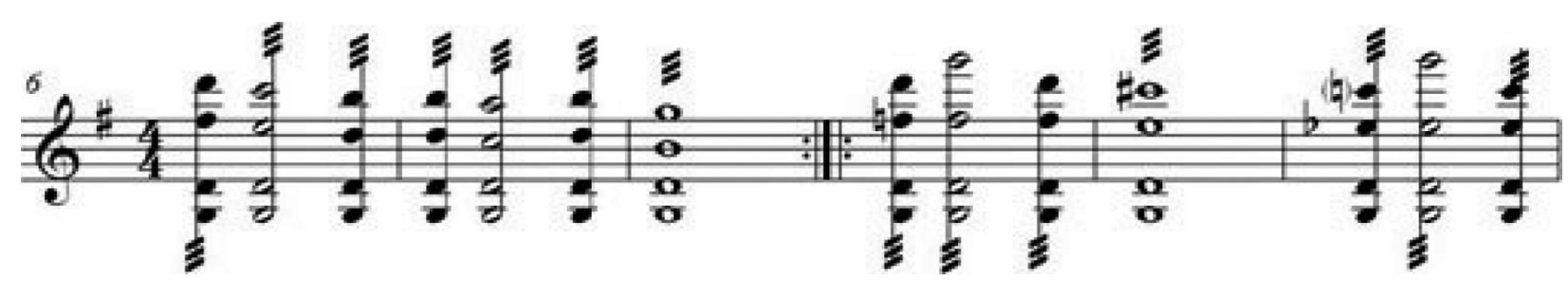

Figura 5: Prelúdio V - Tico-Tico. Comp. 6 - 11.

Esse tipo de escrita musical com textura dominada por arpejos ascendentes e descendentes ligados em golpes de arco ricochet é um procedimento similar ao utilizado em estudos técnicos tradicionais, a exemplo do Estudo No XIX, Opus 35 de Dont. Quando comparado a este estudo, o prelúdio de Vale requer demanda técnica mais acessível, compatível com o nível intermediário de proficiência ao instrumento. No entanto, não se pode tirar o mérito composicional de Vale, acerca do seu conhecimento técnico na utilização dos acordes arpejados em arco ricochet como um recurso importante na linguagem do instrumento. A utilização de tal procedimento revela as evidências sobre a matriz técnica que inspirou Vale a escrever este prelúdio, bem como sua identificação técnica com a escola violinística europeia do século XIX.

O Prelúdio VI, Marcha Fúnebre também apresenta características que o aproxima do gênero estudo. Este prelúdio pode ser aplicado para desenvolver aspectos importantes da afinação harmônica ao violino. Sua concepção técnica é baseada em uma linha melódica simples construída sobre um pedal harmônico alternando-se entre Ré ( $3^{\mathrm{a}}$ corda) e Sol ( ${ }^{\mathrm{a}}$ corda), criando-se desta forma pontos de referência tonal.

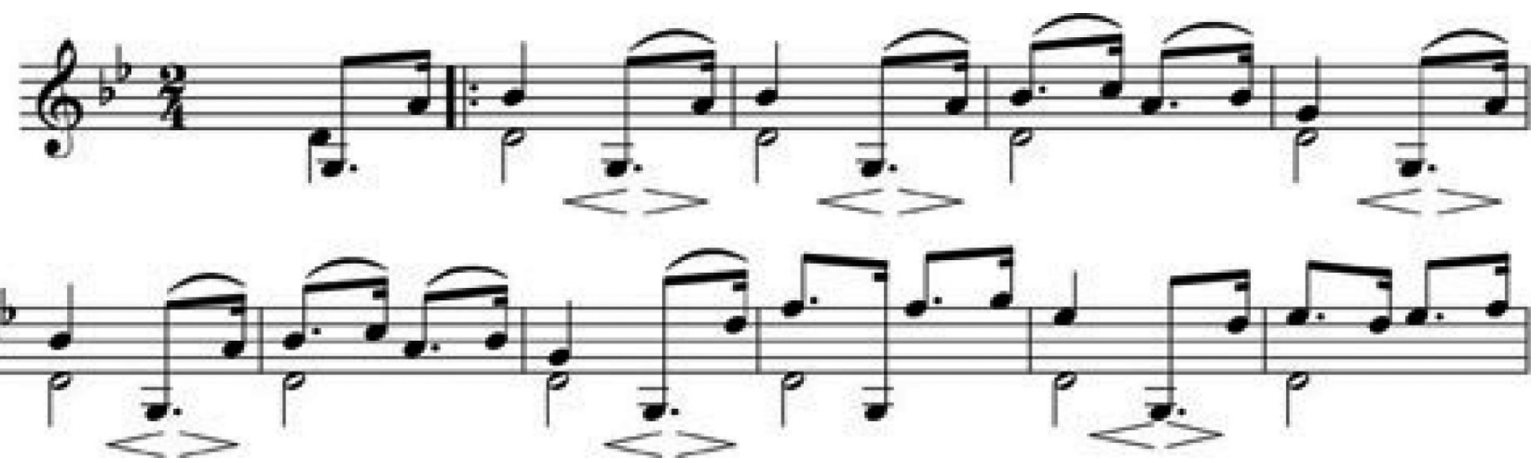

Figura 6: Prelúdio VI - Marcha Fúnebre. Comp. 1 - 11.

A afinação deve ser uma preocupação primária para qualquer violinista. GALAMIAN (1985. p. 19) explica que a aquisição de uma boa afinação é fortemente baseada na sensação de toque dos dedos combinado com o auxílio da orientação auditiva. Como auxiliar da percepção auditiva, o uso de nota pedal para referência tonal é amplamente defendida na prática violinística. Ricci (1988, p. 4) esclarece que "no estudo de escalas a nota pedal, criando uma corda dupla, deve ser usada para garantir uma afinação segura”. Ainda segundo Ricci (1988, p. 4) "é neste fundamento que a construção da técnica da mão esquerda de fato se inicia”. Embora esta abordagem exposta por Ricci não contemple especificamente as nuances da afinação melódica, é em contrapartida muito efetiva na solidificação da fôrma da mão esquerda que irá mais adiante beneficiar tanto a técnica de cordas duplas, quanto o estudo da própria afinação melódica mediante ajustes pontuais.

A nota pedal como referência tonal é novamente usada no Preludio VIII, Repente. Neste prelúdio este fundamento aparece como a seção final desta peça a partir do compasso 32. Embora este fundamento técnico se apresente apenas na seção final, seu uso elege este 
prelúdio para categoria de estudo pois se sustenta pela abordagem técnica equilibrada com o restante do texto musical.

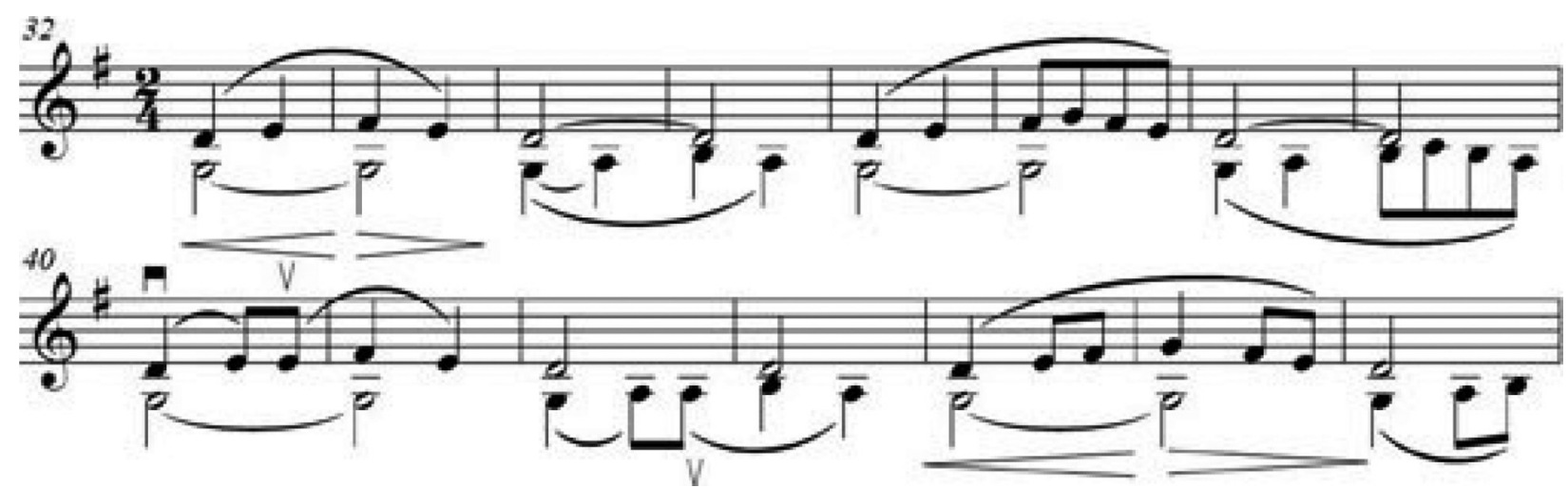

Figura 7: Prelúdio VIII - Repente. Comp. 32 - 46.

No Prelúdio IX, Rondó Doméstico, escrito na forma A-B-A, Vale cria uma seção central contrastando com outras duas de caráter festivo que abre e conclui a peça. Desta forma Vale exige do violinista habilidade de contrapor um tema Allegro da seção A, com o caráter lírico dos legatos exigidos no Cantabile da seção B. A escrita privilegia os golpes de arco spiccato e legato de forma consistente e equilibrada, tornando-se assim um estudo indicado para a prática destes fundamentos da técnica da mão direita. Em adição ao seu foco na técnica do arco, este prelúdio é também consistente em abordar uso de cordas duplas, em especial sextas e terças. Identifica-se na primeira parte da obra, uma predominância dos intervalos de cordas duplas em sexta. Embora Vale faça uso esporádico de outros intervalos na parte central da obra, um segundo tema aparece com o formato intervalar sugerindo estudo em de cordas duplas em terças. Este prelúdio, portanto, torna-se didaticamente interessante e funcional no que se refere a questão técnica específica no uso de intervalos de terças e sexta em adição a sua abordagem de fundamentos da técnica do arco.

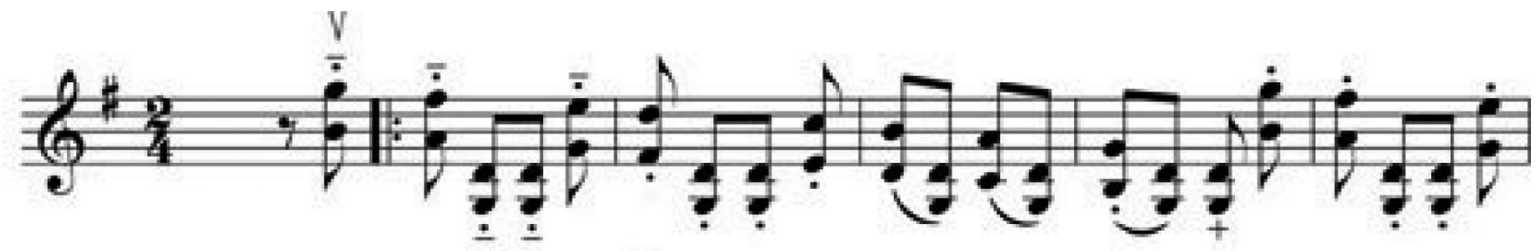

(2)

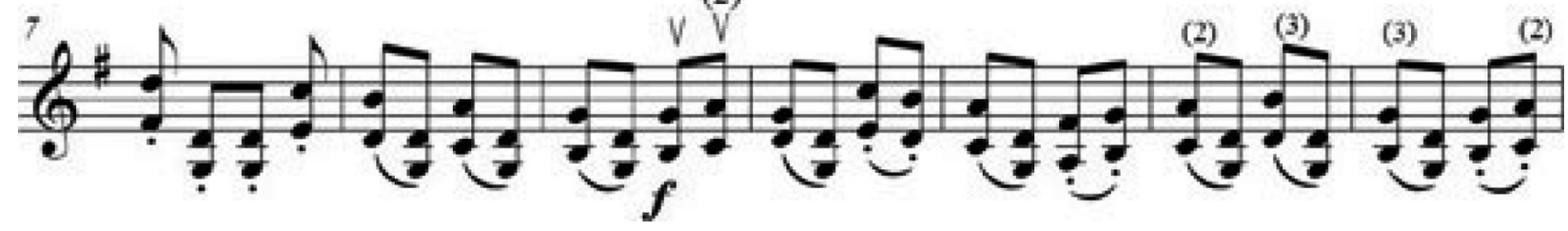

Figura 8: Prelúdio IX - Rondó Doméstico. Comp. 1 - 13. Seção A.

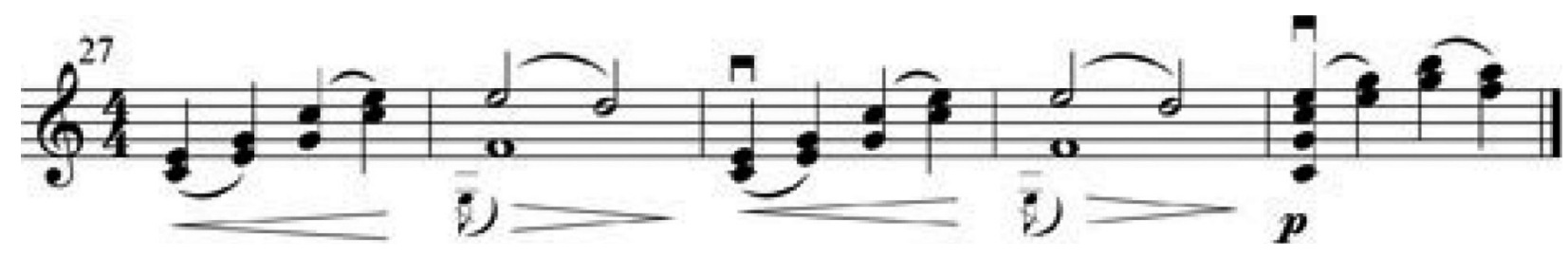

Figura 9: Prelúdio IX - Rondó Doméstico. Comp. 27 - 31. Seção B. 
$\mathrm{Na}$ técnica violinística os intervalos de terças e sextas, executados em cordas duplas com movimento de duas vozes paralelas, representam um importante fundamento técnico. Sua aplicação em obras basilares do repertório é notável, especialmente nos concertos e peças de compositores/violinistas como: Paganini, Wieniawski, Sarasate e Vieuxtemps. Como consequência, a literatura de métodos de estudos é pródiga em abordar seu uso nos mais diversos contextos. Vale, por sua vez, atento a estética da linguagem violinística europeia não se absteve de seu uso nos prelúdios. O Prelúdio XV, Ao Pé da Fogueira, é exemplar no uso destes fundamentos. Escrito em andamento Allegro Comodo, este prelúdio desenvolve-se a partir de um motivo rítmico/melódico que é repetido com discretas variantes durante toda a peça. Em um primeiro instante o compositor usa intervalos de sextas paralelas.

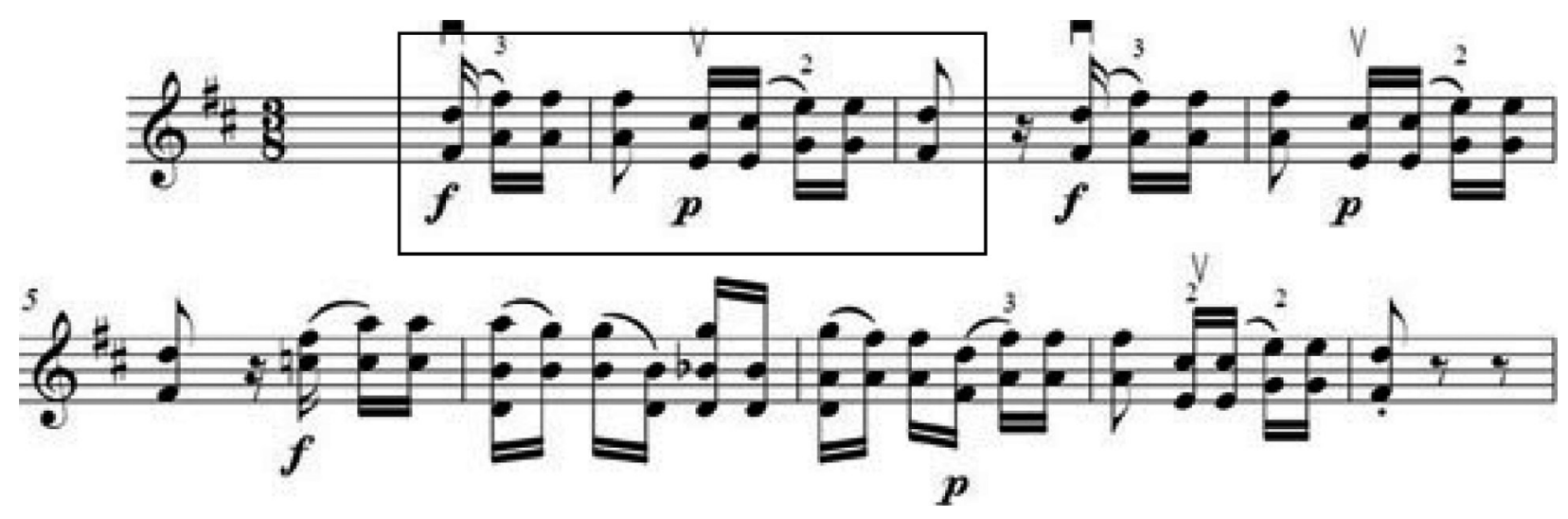

Figura 10: Prelúdio XV - Ao Pé da Fogueira. Comp. 1 - 8. Destaque para a célula motívica.

Na repetição motívica a partir do compasso 12, Vale faz a inversão da voz superior da sexta para a oitava inferior e passa a usar terças paralelas.

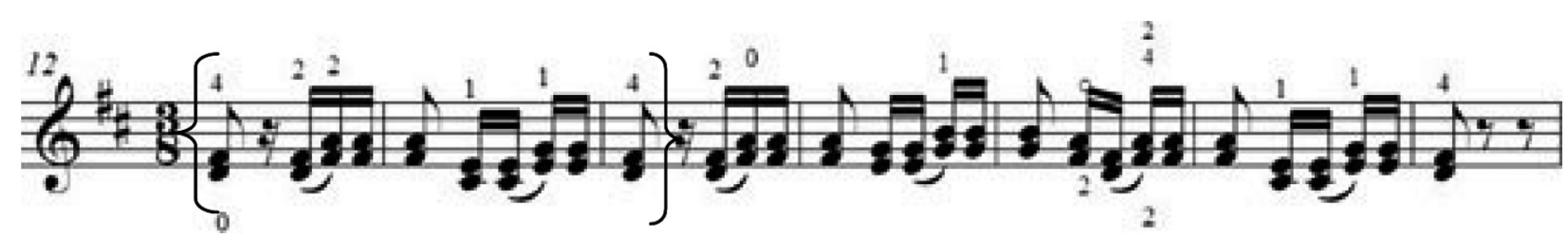

Figura 11: Prelúdio XV - Ao Pé da Fogueira. Comp. 12 - 16.

Uma vez exposto, este tratamento textural é mantido durante toda a peça. Desta forma o Prelúdio $X V$ adequa-se de forma exemplar na abordagem de dois dos fundamentos da técnica da mão esquerda mais recorrentes na literatura do violino, execução de cordas duplas em terças e sextas paralelas.

A seguir veremos o interesse técnico para a finalidade de se adequar ao gênero estudo nos Prelúdios XIII e XXI. Muitos dos elementos técnicos encontrados nos prelúdios selecionados na nossa análise são recorrentes entre os prelúdios. Cordas duplas em terças e sextas, por exemplo são utilizadas em vários prelúdios, especialmente em movimentos paralelos. Indo um passo além da visão meramente técnica, isso deve-se em parte ao caráter da linguagem musical fortemente vinculada a cultura popular do interior do Brasil, em especial a de Minas Gerais. Nos registros das cantorias populares do interior do Brasil é comum o uso de vozes em movimento intervalar paralelo.

No Prelúdio XIII, Asas Inquietas, Vale retorna a forma A-B-A valendo-se de uma seção central em tempo de valsa para contrastar com as seções externas em ritmo binário 
com material motívico idêntico. O maior interesse violinístico encontra-se exatamente na primeira e última seção onde Vale faz uso de um motivo rítmico/melódico que irá permear estas duas seções.

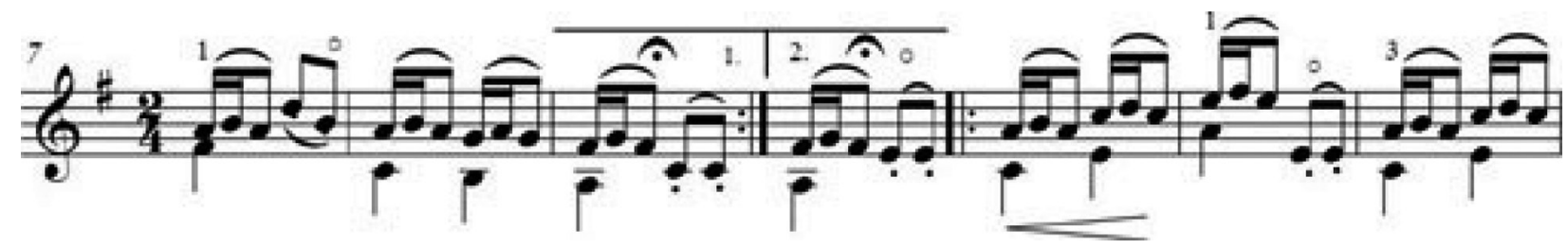

Figura 12: Prelúdio XIII - Asas Inquietas. Comp. 7 - 13.

Aqui novamente o foco concentra-se prioritariamente em intervalos de sextas e terças em cordas duplas. Entretanto, a escrita representa a realização daquilo que poderia ser grafado com uso de mordentes.

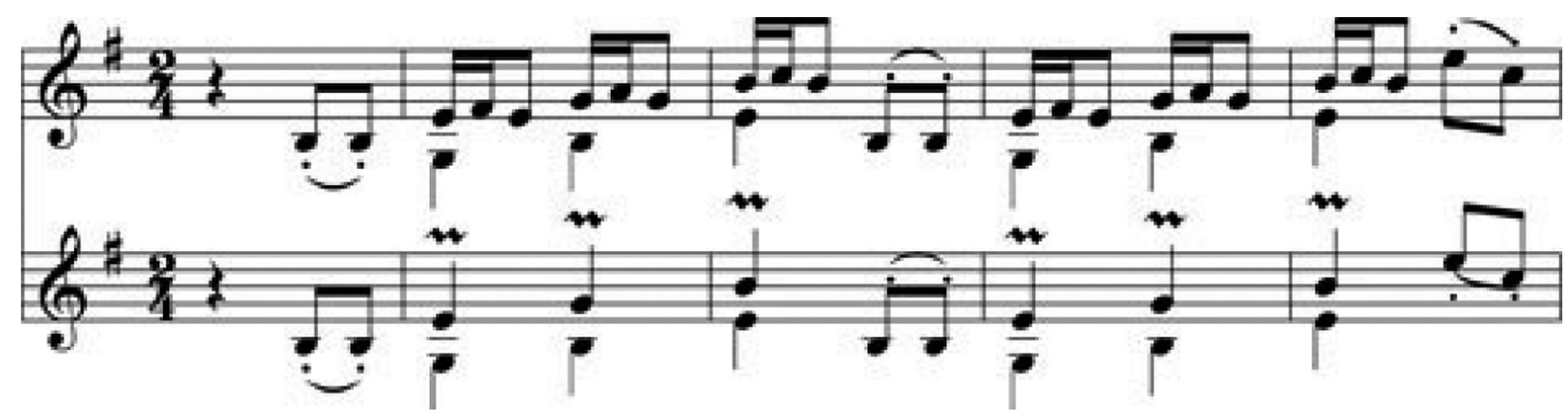

Figura 13: Prelúdio XIII - Asas Inquietas. Comp. 1 - 5.

Ao retornar, a seção A é apresentada em uma oitava acima da inicial. Vale faz uso frequente do recurso de variar elementos motívicos através de recursos da linguagem violinística e cria uma forma interessante de demanda técnica. A repetição de uma determinada passagem em uma oitava acima da anterior implica sempre em novos ajustes da técnica de mão esquerda e arco. Assim sendo, este prelúdio oferece excelente material para prática de cordas duplas com adição de mordente em diferentes regiões no braço do instrumento.

Finalmente, no Prelúdio XXI, Prelúdio da Vitória, Vale novamente utiliza-se de recursos da linguagem técnica do violino para obter variantes. Neste prelúdio o interesse técnico reside principalmente no uso de oitavas paralelas no final da peça como variação aos motivos rítmicos e melódicos iniciais. Por se tratar de um fundamento da técnica do violino que requer especial atenção, estudos para desenvolvimento de oitavas paralelas são recorrentes na literatura. O estudo de oitavas paralelas usando-se o primeiro e quarto dedos da mão esquerda é fundamental para aquisição do que no vocabulário violínistico é chamado de fôrma da mão; o que de fato e em resumo, significa a distância precisa entre primeiro e quarto dedos nas diversas posições no braço do violino. Embora o intervalo de oitava paralela possa ser dedilhado de outras formas, é na fôrma de $1^{\circ}$ e $4^{\circ}$ dedos que este intervalo se apresenta inicialmente na literatura de estudo técnico. 

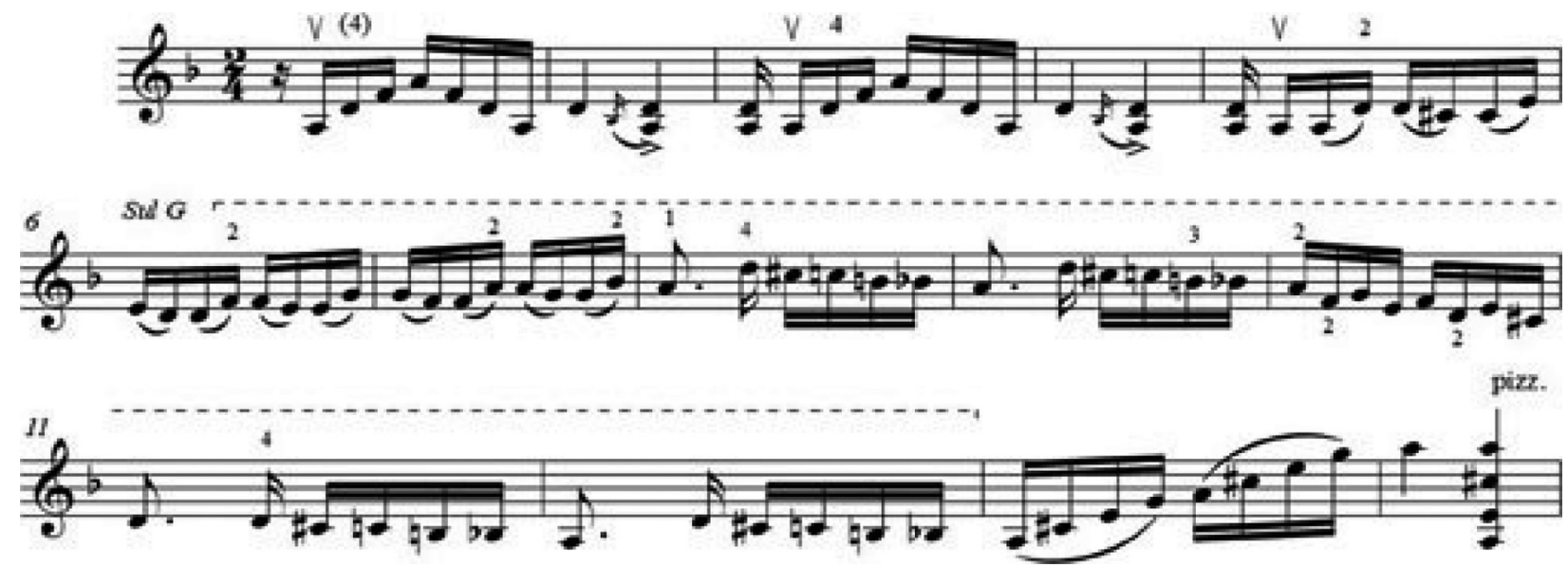

Figura 14: Prelúdio XXI - Prelúdio da Vitória. Comp. 1 - 14.

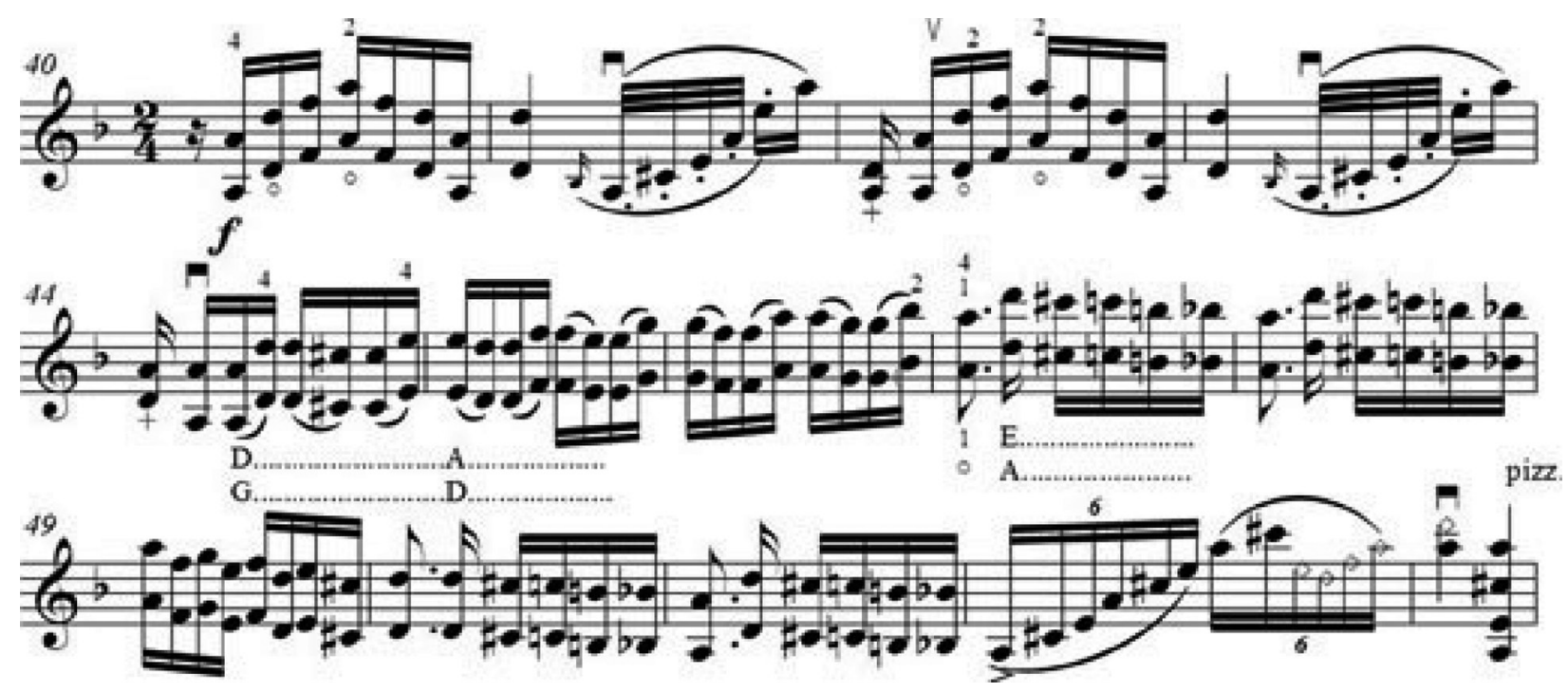

Figura 15: Prelúdio XXI - Prelúdio da Vitória. Comp. 40 - 53.

Embora não tenhamos comentado a totalidade dos prelúdios selecionados com potencial de integrar o gênero estudo, acreditamos que o que foi exposto contempla a essência da linguagem violinística de Vale herdada da tradição europeia e ilustra de forma positiva a vocação destes prelúdios para servir ao interesse didático.

\section{Considerações finais}

Ao comentar sobre seus 26 Prelúdios Característicos e Concertantes para Violino Só, Vale invocava sua adoção nos currículos dos conservatórios como estudos técnicos para o violino. Embora Vale se referisse à totalidade dos vinte e seis prelúdios, em nossa análise ficou confirmado que em apenas quinze dessas peças encontramos de fato elementos passíveis de lhes conferir este status. Acreditamos ser plausível afirmar que Vale ao compor essas peças não tinha em mente seu uso como estudos técnicos. Embora o estilo da linguagem violinística do compositor seja amplamente favorável e contribua para direcionar essas peças para a condição de estudo técnico. Acredita-se que a expressão de seu desejo de atribuir uso didático aos prelúdios, posterior à sua composição, pode ter advindo como consequência da maior visibilidade alcançada, decorrente da exposição pública dos seus prelúdios, e pela divulgação dessas peças feita pelo próprio compositor quando ainda vivia. 
Vale posiciona-se eclético em sua linguagem violinística. Entretanto, em alguns prelúdios seu foco é bem definido em determinados fundamentos técnicos. Nos quinze prelúdios que foram selecionados por seu potencial como estudos, Vale se afasta do uso de recursos técnicos violinísticos não convencionais, como aqueles associados à caracterização da linguagem musical adotada em determinados prelúdios. Nos prelúdios selecionados, o que encontramos em termos de linguagem técnica é fortemente influenciada pela técnica violinística utilizada nas obras de compositores/violinistas da Europa no Sec. XIX. Observamos ainda que essas características estão em parte associadas a chamada escola violinística Franco-Belga, representada por compositores como: Vieuxtemps, Beriot e Gaviniès. A aproximação de Vale com esta escola violinística já era potencialmente esperada e decorrente em parte do curto período de estudo com seu tio João Augusto Campos, seu único professor e formado sob os ditames da escola Franco-Belga.

O potencial uso pedagógico dos prelúdios selecionados é, portanto, viável e reputamos importante para a cultura violinística nacional. Muito mais do que reproduzir padrões e fundamentos da linguagem técnica europeia, há que se considerar que Vale o faz no contexto de uma linguagem musical estreitamente associada a cultura da música popular e folclórica do interior do Brasil. Sob esta ótica os prelúdios são únicos e aqueles selecionados como estudos deveriam ser fundamentais na formação do violinista no Brasil. A personalidade inquieta e observadora de Vale associada ao seu talento e espontaneidade ao violino nos deixa um legado valioso para a literatura brasileira do violino.

\section{Notas}

1 Este livro foi publicado posteriormente ao Estudo de Folclore (1934) de Luciano Gallet e ao Ensaio Sobre Música Brasileira (1928) de Mário de Andrade

2 Campos foi um dos melhores alunos de Manoel Joaquim de Macedo. Macedo, por sua vez, estudou na Bélgica com Vieuxtemps e Beriot, sendo posteriormente violinista da orquestra do Convent Garden em Londres.

3 Corda não pressionadas por dedos da mão esquerda.

\section{Referências}

ALVARENGA, Hermes. Os 26 Prelúdio Característicos e Concertantes para Violino Só, de Flausino Vale: Aspectos das Linguagens Musical e Violinística. Dissertação de Mestrado. Instituto de Artes, 1993, UFRGS. Porto Alegre. 116p.

BRANDT, Celso. Flausino Vale, o novo Paganini. Jornal Diário da Tarde. Belo Horizonte. 8 de outubro de 1947.

FRÉSCA, Camila. Uma Extraordinária Revelação de Arte: Flausino Vale e o Violino Brasileiro. São Paulo: Annablume/FAPESP, 2010. 204p.

GALAMIAN, Ivan. Principles of Violin Playing and Teaching. 2. ed. New Jersey: Prentice-Hall, 1985. $144 \mathrm{p}$.

MURICY, Andrade. Pelo Mundo da Música - Flausino Vale. Folhetim do Jornal do Comércio. Rio de Janeiro. 31 de março de 1948.

MILEWSKI, Jerzy. Flausino Vale: Prelúdios Característicos e Concertantes para Violino Só. LP 84045. FUNARTE, 1984. 
PAULINYI, Zoltan. Flausino Vale e Marcos Salles: Influências da escola franco-belga em obras brasileiras para violino. Dissertação de Mestrado. Instituto de Artes, 2010, UNB. Brasília. 163p.

RICCI, Ruggiero. Left-Hand Violin Technique. New York: G. Schirmer Inc. 1988. 56 p.

\section{Partituras}

VALE, Flausino. 26 Prelúdios Característicos e Concertantes para Violino Só. Revisão de Camila Frésca e Claudio Cruz. São Paulo: Editora Criadores do Brasil/OSESP, 2011.

Hermes Cuzzuol Alvarenga - Professor Associado de Violino do Departamento de Música da UFPB onde orienta alunos dos cursos de Extensão, Graduação e Pós-Graduação. Natural de Vitória, ES. em 1980 transferiu-se para João Pessoa, PB passando a integrar a OSPB como violinista. Hermes é Doctor of Musical Arts pela The University of Iowa, nos Estados Unidos, Mestre em Música pela UFRGS em Porto Alegre e Bacharel em Música pela UFPB.

Paulo Leniuson Mota Ribeiro - Violinista Mestre em Música pela UFPB. Especialista em Arte e Educação com ênfase em Música pela Faculdade Vale do Jaguaribe (FVJ). Professor da disciplina de Introdução ao Ensino da Música na Faculdade Darcy Ribeiro e de Teoria Musical da Faculdade Vale do Jaguaribe. Atualmente é músico/spalla, regente assistente e membro da comissão artística da Orquestra de Câmara Eleazar de Carvalho. Possui diversos trabalhos como Arranjador, Compositor e Produtor Musical. 